Távol-keleti Tanulmányok 2016/1: 41-66.

DOI: 10.38144/TKT.2016.1.3

Albeker András Zsigmond

\title{
Rozsnyai Japán nyelvmestere ${ }^{1}$
}

\section{Bevezetés}

Az 1904-ben kitört orosz-japán háború eseményeit Magyarországon is nagy érdeklődéssel figyelték. Japánnal vagy az orosz-japán háborúval kapcsolatban számos kiadvány, illetve újságcikk, tudósítás látott napvilágot, ${ }^{2}$ és ehhez az időszakhoz köthető az első magyarországi dzsúdótanfolyam is. ${ }^{3}$ Szintén ebben az időben jelent meg a Rozsnyai gyors nyelvmesterei sorozat tizenötödik köteteként az elsô magyar nyelven összeállított japán nyelvtan és társalgás. Hosszú ideig ez lehetett az egyetlen japán nyelvtan: a Japán Alapítvány budapesti irodája által összeállított tankönyvlista szerint az ezt követő nyelvkönyv csak 1970-ben jelent meg. ${ }^{4}$

A Rozsnyai kiadó japán nyelvtana a Meiji-kori nyelvet tükrözi, a kiejtésben és a nyelvtanban nyugat-japáni (kansai 関西) jellegzetességek is megfigyelhetők. ${ }^{5}$ Mivel magyarok számára állították össze, a nyelvtani és a kiejtési magyarázatokban a magyar nyelvvel való összehasonlítások is megtalálhatóak.

E könyvecskével korábban Kondō Masanori 近藤正憲 foglalkozott egy tanulmányában. ${ }^{6}$ Kondō feltételezése szerint a nyelvtan összeállítója

Jelen cikk az alábbi tanulmány átdolgozása: Albeker András 2011. „Rojunyai Nihongo sokushū no chosha to shutten ni tsuite ロジュニヤイ『日本語速習』の著者と出典に ついて [Rozsnyai Japán nyelvmesterének szerzője és forrásai].” Kyōto daigaku kokubungaku ronsō 京都大学國文學論叢 26: 23-38. A cikk elkészüléséhez segítséget nyújtottak: Albeker Melinda, Cseresnyési László, Károlyi Orsolya, Kiss Sándor, Pósfai István, Tóth Gergely, Vincze-Pikó Adrienn, Yoshikai Naoto, valamint a Japán Országgyúlési Könyvtár könyvtárosai.

2 Harangi 1982: 376-417.

3 Sasaki 1907.

4 „Hangarī no nihongokyōzai risuto ハンガリーの日本語教材リス卜 [A magyarországi japán nyelvi oktatóanyagok listája].” 2009. X.

5 Néhány példa a könyvből a kelet- és nyugat-japáni nyelvi különbségekre: atta-ota [sic!] 'találkozott' (4.oldal), konomanai-konomanu 'nem kedvel, nem szeret', konomanakatta-konomananda 'nem kedvelt, nem szeretett' (21. oldal).

6 Kondō 2005: 175-192. 
hosszabb időt tölthetett Japánban, ahol nyugat-japáni nyelvi hatások is érhették a nyelv tanulása során.

Jelen tanulmány elsődleges célja a nyelvtan szerzőjének személye és az általa használt források meghatározása. A kutatás kezdeti szakaszában az OSZK-ban található példány ${ }^{7}$ fényképeit használtam, de később sikerült hozzájutnom egy jó állapotban lévő példányhoz az egyik budapesti antikváriumból. A könyv felépítésének jobb megértéséhez ugyanebből a sorozatból a szlovák és az angol nyelvtant is felhasználtam.

\section{A könyv rövid bemutatása}

A borítón magyar és német nyelven a következő olvasható:

Rozsnyai / Gyors / nyelvmesterei / Bármely nyelv / alapos elsajátítására / tanító nélkül / Japán / Ára 1 korona / Gyakorlati / Japán-magyar-német / beszélgetésekkel / Hét eredeti japán-írástáblával / A kiejtés pontos feltüntetésével / Japanische Grammatik / Praktische / Japanisch-Ungarisch-Deutsche / Conversation / Mit sieben original-japanischen Schrift-Tabellen / mit Bezeichnung der Aussprache / Ohne Lehrer / Rozsnyai Károly Budapest, IV., Muzeum-körút 15.

A szerző neve, valamint a kiadás éve nincs feltüntetve, de Kondō tanulmánya 1905-re, A magyar írók élete és munkái 1906-ra teszi a könyv megjelenését. A Budapesti Hirlap 1905. VII. 9-i számában olvasható könyvismertetés ${ }^{8}$ Kondōt igazolja. A borító belső oldalán tartalomjegyzék, a japán mértékegységek, pénznemek, a hónapok nevei és a sorozat eddig megjelent köteteinek címei láthatók. A hátsó borítón és annak belső oldalán a Rozsnyai

OSZK B1 621.067. Amicus azonosító: 3196137.

8 „(Japán nyelvtan.) Rozsnyay Károly rövid gyakorlati japán nyelvtant adott ki, melyből tanitó nélkül is el lehet sajátitani a japán nyelv elemeit. A füzet a nyelvtani szabályokon kivül beszélgetéseket is közöl a kiejtés pontos megjelölésével. Van benne szótár s több japáni irástábla is. A munka ára egy korona, megrendelhetô a Budapesti Hirlap könyvkiadóhivatalában is." 
kiadó zenepedagógiai könyveinek bemutatása olvasható. A nyomda címe a hátsó borítón, legalul van feltüntetve: „Révai és Salamon könyvnyomdája. Budapest VIII. Üllói út 18".

Az első oldalon nincs előszó, de a címlapon olvasható „tanító nélküll”-ből arra lehet következtetni, hogy önálló tanulásra szánták. A teljes könyv 64 számozott oldalból áll, és a következő részekre osztható:

1. Nyelvtan 1-34. oldal

2. Beszélgetések 35-47. oldal

3. Magyar-japán szótár 48-56. oldal

4. A japán írásról 56-64. oldal

Az utolsó fejezet hét írástáblát is tartalmaz, melyek a következők:

I. Számjelek

II. Katakana írásjelek [sic!]

III. Hiragana írásjelek [sic!]

IV-VII. Japáni írásminták, átírással s fordítással.

Az írástáblákat leszámítva a könyv teljes japán szövege latin betúkkel íródott. Kétféle átírást alkalmaz a könyv, az első, az ,általános használatban lévő átírás” a japán Rōmaji Kai 羅馬字會 (Latin Betús Társaság) által kidolgozott rendszerrel mutat hasonlóságot. Azonban attól eltéróen a nyújtóhangot nem a magánhangzó fölé tett vízszintes vonallal ( $\bar{a}, \overline{1}, \bar{u}, \bar{e}, \bar{o})$, hanem magyaros ékezettel jelöli (á, í, ú, é, ó).

9 A Rōmaji Kai 1885-ben alakult, a latin írásos rendszerük kidolgozásakor japán és külföldi tudósok véleményét is figyelembe vették. A mássalhangzók jelölésekor az angol, a magánhangzók esetében pedig az olasz (német, latin) nyelv írásmódját vették alapul. Mivel James Curtis Hepburn japán-angol szótárának harmadik kiadásában (A Japanese-English and EnglishJapanese Dictionary, 1886) ezt az átírási rendszert alkalmazta, így az végül Hepburn-átírás néven vált ismertté. Korabeli forrásként lásd: Rōmaji nite nihongo no kakikata. Rōmaji Kai, 1886. 
A második rendszer a „kiejtés pontos feltüntetése”, azonban ezt nem tartja be mindig, ezért megfigyelhető némi ingadozás, következetlenség. A két rendszer különbségeirôl lásd az alábbi táblázatot:

\begin{tabular}{|c|c|c|c|}
\hline hiragana & átírás 1. & átírás 2. & példa \\
\hline ああ & á & $\widehat{\mathrm{aa}}$ & babá / babāa: 'öreg asszony' \\
\hline が & ga & nga & arigató / aringatoo: 'köszönöm' \\
\hline さ & sa & sza & sake / szake: 'rizsbor' \\
\hline L & shi & si & shi / si: 'négy' \\
\hline じ, ぢ & ji & zsi & ei-jin / ei zsin: 'angol' \\
\hline$ち$ & chi & csi & chichi / csicsi: 'atya' \\
\hline$\supset$ & tsu & $\mathrm{czu}$ & kizetsu / kizeczu: 'ájulás' \\
\hline ひ & hi & chi & hito / chito: 'egy' \\
\hline 3. & $\mathrm{fu}$ & fhu & futa / fhuta: 'kettő' \\
\hline ひゃ & hya & cha & hyaku / chaku: 'száz' \\
\hline わ & wa & wa, ua & chawan / csauañ: 'csésze' \\
\hline h & $\mathrm{n}$ & $\mathrm{n}, \tilde{\mathrm{n}}$ & chawan / csauañ: 'csésze' \\
\hline
\end{tabular}

A magánhangzó-zöngétlenedést az illető magánhangzó elhagyásával jelöli, pl uataksi (watakushi: 'én'), chtocz (hitotsu: 'egy').

\section{A Rozsnyai kiadóról}

Rozsnyai Károly 1889-ben nyitotta meg könyvesboltját, ahol kezdetben használt könyveket árult, majd egyetemi jegyzetek, tankönyvek, zenemúvek kiadásába is belefogott. ${ }^{10}$ A Gyors nyelvmester sorozat első kötete, a Magyar nyelvmester 1900-ban jelent meg. Az OSZK adatbázisa, valamint a szlovák és angol nyelvmesterben található lista alapján a következő nyelvek jelentek meg a sorozatban: magyar, német, francia, angol, olasz, orosz, spanyol, portugál, latin, román, szlovák (tót), szerb, horvát, cseh, japán, héber, lengyel,

10 Révay 1929: 100-101. 
újgörög, török, eszperantó, bolgár, holland. A kötetek elsősorban az OsztrákMagyar Monarchia, illetve a környező országok nyelveit oktatják, de keleti nyelvként a héber, a japán és a török is helyet kapott.

$\mathrm{Az}$ egyes kötetek felépítése hasonló: nyelvtani magyarázat, társalgás német fordítással. Az eszperantó és a bolgár kötetekben szótár, a japán és a török kötetekben pedig szótár és írástanító rész kapott helyet. A holland nyelvmester társalgása és szójegyzéke külön kötetekben jelent meg. Az egyes kötetek között van olyan is, amely bővítve többször is kiadásra került, de a japán esetében ezzel kapcsolatban jelenleg nincs információ. A Gyors nyelvmester sorozat mellett a Rozsnyai nagy nyelvtana sorozat is megjelent. Ez utóbbi az orosz, német, angol, szerb, román, francia nyelvek nyelvtanát tárgyalja, de keleti nyelvek nem kerültek bele ebbe a sorozatba.

\section{A szerzőről}

Ahogy a tanulmány elején is említettem, a szerző nevét nem tüntetik fel a borítón, de a Magyar nyelv 2004. évi 4. számában Koósz István olvasói levele Akantisz Viktort nevezi meg szerzőnek, hivatkozva a Magyar írók élete és munkái címú kiadványra (a továbbiakban MIÉM). Ennek és más forrásoknak $^{11}$ az adatai alapján a következóket lehet megtudni Akantiszról. Akantisz Viktor, eredeti nevén Akantisz Győző Béla Ernesztusz, 1864. december ötödikén született Jászfényszarun. Apja, Akantisz Ignác nótárius, anyja nemes Ozorótzky Ilona. Keresztanyja özv. Görög Amália, keresztapja Elefánty Ernesztusz jászberényi medikus. A jászberényi középiskola elvégzése után Budapesten hallgatott filozófiát és jogot, majd hosszabb ideig grafikusként és íróként-fordítóként tevékenykedett. Írói álneve A. V. , illetve Fréron A. V. volt.

A Rozsnyai kiadó számára olajfestészetet, sakkot oktató könyveken kívül a Gyors nyelvmesterek sorozat német, francia, angol, olasz, orosz,

11 Magyar Országos Levéltár, A 1154, 369/5 kötet p. 3; 60. Gulyás 1939: 319-320. Pelbárt Jenő: Papír-és vízjeltörténet, http://www.mol.gov.hu/papir_es_vizjeltortenet/a_magyar_papir_es_ vizjelkataszter_jovoje.html (megtekintve 2011. VIII. 14); Pukánszkyné 1972: 52-60. 
spanyol, portugál, japán, lengyel, cseh, török nyelvi köteteit is ő állította össze. Akantisz a Magyar Lányok, Természettudományi Közlöny, Új Idók címú folyóiratokban is publikált, de 1910-ben - írói tevékenységét abbahagyva - Todoreszku Gyula könyvgyújtő könyvtárának rendezésébe fogott bele. Todoreszkuval közösen összeállított egy vízjel-katalógust is, de ez végül nem került kiadásra. 1919-1929 között a Nemzeti Múzeumban dolgozott könyvmúvészeti előadóként. Akantisz 1943. október 21-én hunyt el, a gyászjelentés szerint a foglalkozása a Magyar Nemzeti Múzeum könyvmúvészeti szakelőadója, az Országos Magyar Hadimúzeum Egyesület tudományos tagja, festômúvész és író volt.

Felesége neve Ligeti Mária, 1896. május harmincadikán keltek egybe. Gyermekeik Camilla, Győző, Lúcia, Georgina, Miklós, Cornél és Virgil. ${ }^{12}$

Akantisz japán nyelvi tanulmányairól, esetleges japán utazásáról nem tudni, azonban nem kizárt, hogy Budapesten találkozhatott japánokkal. ${ }^{13} \mathrm{~A}$ Japán nyelvmestert megelőzően egy japán mesegyújteményt is összeállított saját illusztrációival, amely Harangi László bibliográfiája alapján az első magyar nyelvú japán mesegyújtemény lehetett. ${ }^{14}$

\section{Akantisz forrásai}

Akantisz Viktor a Japán nyelvmester megírásakor vajon milyen anyagokat vehetett alapul? Az Edo-kor végétól 1905-ig megjelent japán nyelvtanok és szótárak - például Chamberlain, Hoffmann, Rosny, Seidel könyvei - az Osztrák-Magyar Monarchia területén is elérhetők lehettek. Ezeket összevetve a Japán nyelvmesterrel, a legtöbb hasonlóságot August Seidel munkáival találtam. ${ }^{15}$

August Seidel Helmstedtben született 1860. szeptember huszonkilencedikén. Halléban keleti és klasszikus nyelveket tanult, majd 1890-1903

\footnotetext{
$12 \quad$ Vincze-Pikó Adrienn közlése. 2014. III. 16.

13 Tóth 2010: 49-97.

14 Japáni mesék. Az ifjuság számára átirta és illusztrálta Akantisz Viktor. Szent István Társulat, 1901.

15 A források listáját lásd a tanulmány végén.
} 
között a Deutsche Kolonialgesellschaft berlini irodájában dolgozott. Az 1890-es évektól kezdve afrikai, ázsiai, európai nyelvek tankönyveit, illetve japánok számára német nyelvkönyvet állított össze. Szerkesztője volt még a Zeitschrift für afrikanische, ozeanische und ostasiatische Sprachen címú folyóiratnak is. ${ }^{16}$ Arról, hogy járt-e Japánban, nem találtam információt. Seidel munkái közül Akantisz az alábbiakat használhatta fel:

1. Praktische Grammatik der japanischen Sprache. Hartleben, 1890 (a továbbiakban PGJS). Az írott és beszélt japán nyelv nyelvtanának öszszefoglalása. A japán szavakat, mondatokat olyan latinbetús átírásban ${ }^{17}$ adja meg, amelyben az [s] és a [z] hangok jelölése a német helyesírás hatását tükrözi. A kötet végén táblázatban a kana 仮名 szótagírás, 660 kanji 漢字, illetve azok összetételei, a kínai írásjegyek gyökeinek felsorolása, valamint szövegmutatványként bibliai idézetek találhatók.

2. Grammatik der japanischen Umgangssprache. Hartleben, 1901 (GJU). A fenti PGJS javított kiadása, de csak a beszélt nyelvet tárgyalja. Az átírás a Rōmajikai rendszerén alapul. Irodalomjegyzék nincs, de az előszó szerint a nyelvi példákat japán könyvekből vette.

3. Grammatik der japanischen Schriftsprache. Hartleben, 1904 (GJS). Az írott nyelv nyelvtanát tárgyalja. A latin betús átírás a Rōmajikai rendszerén alapul, de az olvasmányok kana írással és kanji-kana vegyesírással is olvashatók. A könyv a hiragana és katakana szótagírásokon kívül tartalmazza még a 214 gyök és 354 gyakran használt kanji táblázatát is.

4. Systematisches Wörterbuch der japanischen Umgangssprache. Schwartz, 1904 (SWJU). Tematikus szótár, a következó 15 témában csoportosítja a japán szavakat latin betûs átírásban:

16 Brockhaus' Kleines Konversations-Lexikon, 1911: 683. Brockhaus' Konversationslexikon, 1894-1896: 935-936.

17 Példa a könyvből: Anata-ga nan-no yuhe-ni Nitupon-go-wo manabi-massenu-ka? (32. oldal.) A massenu végződésben az „„” kettőzését az indokolja, hogy a német olvasó [z] -t ejtene benne: Fusel ['fu:zəl] 'lőre', de Fussel ['fusəl] 'szösz'. Ugyanez a mondat a ma széles körben használt Hepburn-átírással: Anata ga nan no yue ni nippongo wo manabimasen ka? 
1) Allgemeine Begriffe. 2) Gott, Religion, Kirche. 3) Welt, Erde, Himmelserscheinungen, Wetter. 4) Die Naturreiche. 5) Der Mensch. 6) Der moralische Mensch. 7) Der kranke Mensch. 8) Familie und Verwandtschaft. 9) Menschliche Bedürfnisse. 10) Schule. Bildung. 11) Die Arbeit. 12) Der Staat. Die Obrigkeit. 13) Krieg und Frieden. 14) Kunst und Wissenschaft. 15) Spiele, Vergnügungen, Feste. Az átírás a Rōmajikai rendszerén alapul, a zöngétlen magánhangzókat aposztróffal jelöli. A címszavakban az igék záróalakban (shūshikei 終止形) szerepelnek, de az egysoros igéknél (ichidan dōshi一 段動詞) a -ru る végződést többnyire kötójellel választja el az igetőtől. A melléknevek szintén záróalakban szerepelnek.

\section{A nyelvtani magyarázatok}

A nyelvtant tárgyaló első rész az alábbi 14 alfejezetből áll: 1) A japán beszédbeli hangok s azok kiejtése. 2) Szótagcsoportok keletkezése. 3) Hangváltozások (hanglágyítás). 4) A hangsúly. 5) A főnév. 6) A melléknév. 7) A névmás. 8) Számnevek. 9) Határozó szók. 10) Elöljárók, névutók. 11) Ragok. 12) Kötszók. 13) Az igék. 14) A szóképzés.

Akantisz a Japán nyelvmester összeállításakor Seidel japán nyelvtanait vehette alapul. Az alábbiakban összefoglalom, hogy a Japán nyelvmester nyelvtani magyarázatainak mely részei alapulhatnak Seidel munkáin:

\begin{tabular}{l|l}
\hline Japán nyelvmester & Seidel munkái \\
\hline p. 3. A kettős mássalhangzók. & GJU pp. 2-3. \\
$\begin{array}{l}\text { pp. 3-4. Szótagcsoportok } \\
\text { keletkezése. }\end{array}$ & GJU p. 2. \\
\hline p. 4. Hangváltozások. & GJU pp. 3-4. \\
\hline p. 4. A hangsúly. & GJU p. 3. \\
\hline pp. 4-5. A főnév. & GJU pp. 16-21. \\
\hline pp. 6-7. A melléknév. & $\begin{array}{l}\text { GJU pp. 28-29;32. PGJS pp. } \\
\text { 65-66; 85. }\end{array}$ \\
\hline
\end{tabular}




\begin{tabular}{l|l}
\hline pp. 7-11. A névmás. & GJU pp. 21-28. \\
\hline pp. 12-15. Számnevek. & GJU pp. 59-70. PGJS pp. 52-55. \\
\hline pp. 16-19. Határozószók. & GJU pp. 70-83. \\
pp. 19-20. Elöljárók, névutók. & GJU pp. 83-85; 107-111. \\
\hline Ragok. & $\begin{array}{l}\text { GJU pp. 85-86; 111-113. PGJS } \\
\text { pp. 20-21. Kötszók. }\end{array}$ \\
\hline pp. 21-31. Az igék. & GJU pp. 33-59; 104-107. \\
\hline pp. 31-34. A szóképzés. & GJU pp. 5-15. \\
\hline
\end{tabular}

Az alábbiakban bemutatok néhány példát a hasonlóságot mutató részekből:

Japán nyelvmester p. 4.: „Japán nyelvben a hangsúly alig van s ép ugy, mint a franczia, egyforma hangsúlylyal mondja ki a szótagokat s csupán a szóhangsúly (a mondatban) hoz egy kis változatosságot az egyhangu beszédbe.”

GJU p. 3.: "Der Wortton wird im Japanischen wenig markiert. Der Japaner spricht vielmehr, wie der Franzose, so, dass er jede einzelne Silbe mit gleichmäßig starker Betonung versieht und nur durch den Satzton etwas Abwechslung in dieses Einerlei bringt."

Japán nyelvmester p. 12.: „A japáni számsor személyeknél nem alkalmazható, mint főnevek szerepelnek s ezért a szavak mellett, sajátító esetben azok előtt, vagy pedig mint utószók, a fónév után állanak (...)”

GJU p. 59.: „Die japanische Reihe wird nicht von Personen gebraucht. Diese Zahlen sind eigentlich Hauptwörter und treten daher entweder im Genitiv vor oder häufiger als Apposition hinter das Hauptwort (...)" 
Japán nyelvmester p. 21. : „A kötszók kevés szerepet játszanak a japán nyelvben, mert egy mondatnak a másik mondat alá való rendelése sok esetben minden további körülmény nélkül csupán az alárendelő formával ( wa és mo) vagy a feltételes formával történik. A kötszó rendesen a mellékmondat végén áll.”

GJU p. 111.: „Die Bindewörter spielen im Japanischen eine weniger wichtige Rolle, da die Unterordnung eines Satzes unter einen andern in vielen Fällen ohne weiteres durch die Subordinationsform (mit oder ohne wa und mo) oder durch die Conditionalformen bewirkt werden kann. (...) Die meisten satzverbindenden Conjunctionen stehen am Ende des Nebensatzes;"

Azonban a Japán nyelvmesterben vannak olyan részek is, amelyek a magyarral összevetve próbálják elmagyarázni a japán kiejtést, nyelvtant. Ezek a részek természetesen nem találhatók meg Seidelnél, valószínúleg Akantisz ismeretein, megfigyelésein alapulhatnak. A hosszú időtartamú japán magánhangzók és a magyar hosszú magánhangzók különbségét (p. 1.) a következőképpen magyarázza:

„Hogy ezt jobban megértessük, vegyünk összehasonlító példákat: a magyarban a rövid s hosszú magánhangzók egynek hangzanak, s ugyanegy idôtartamuak s csupán a száj meg torok zártabb s nyiltabb helyzete által képződik, pl.: gaz, gáz; mez, méz stb. Japán kiejtésben ez máskép hallatszik és pedig ugy, mintha a rövid magánhangzót kétszer olyan hosszú idótartamig mondanók ki, mint a valóban rövidet. Tehát csupán időtartamban nyúlik meg és nem a hangban magában. Jó példa erre pl.: a magyar palócos kiejtés: így ,alma” tiszta kiejtésben az első szótag röviden kimondott $a$, palócosan pedig āma aâma: szintén rövid az, de időtartalomban van elhúzva. Azt hiszszük ezen példa érthetővé teszi és megvilágosítja a magyar és 
japán hosszú magánhangzók kiejtése közt levő különbséget. A japánban is - úgy mint magyarban - különösen ügyelnünk kell a magánhangzók (szótagok) rövid vagy hosszú kimondására, mert sok különböző értelmü szók csak is ez által különböznek egymástól."

A 16-17. oldalon a hangutánzó és hangfestő szavak esetében szintén hoz magyar példákat:

„Idetartozik még sok olyan kettőzés is, mely épen ezen kettozött hanggal fejezi ki az állapotot, ténykedést; ilyen szóhalmozás a magyarban is megvan, mint gyakoritó szó szerepel, pl.: szerte-szét (mindkét szó egyértelmü, de igy együtt tágabb jelentőségü), ide s tova, innen-onnan; ehhez hasonló czélra szolgál s hasonló értelmezést fejez ki a japánban szokásos szókettőzés is.”

Ezt követően felsorol közel 50 ilyen határozószót, amelyek közül 11-hez párosít magyar ikerszót: dokadoka to: kopogva menni (kip-kop); gougou to: harangszó (ging-gang); kirakira to : világit (csillog-villog a fény); pichipichi: csapkod (a hal a farkával: pics-pacs) stb. 


\section{Társalgás}

A Beszélgetések címú részben 244 kifejezés, mondat van a következő 14 téma alapján csoportosítva: ${ }^{18}$ 1) Kérdezni. 2) A japáni beszédről. 3) A lakás. 4) Az evés. 5) Az ivás. 6) A reggeli. 7) A fürdó. 8) A posta. 9) Az óra. 10) Az időről. 11) Az egészségről. 12) Beszédbe ereszkedni. 13) Vasuton. 14) Hajón. A társalgási rész felépítése hasonló az angol és a szlovák nyelvmesterhez: magyar mondat - német mondat - japán fordítás - kiejtés. Az ebben a részben felsorolt mondatok között vannak olyanok, amelyek a GJU-val összevetve hasonlóságot mutatnak.

Japán nyelvmester (p. 35.): Watakushi wa anata wo sukeraruru no wo yorokibamasu [sic!].

GJU (p. 166.): Watak'shi wa anata wo sukeraruru no wo yorokobi-mas'!

Japán nyelvmester (p. 47.): Anata wa dare zo watashi no nimotsu wo fune made notte [sic!] itte kureru mono wo shitte imasu $k a$ ?

GJU (p. 160.): Anata darezo watak'shi no nimots'wo fune made motte itte kureru mono wo shitte i-mas'ka.

18 Összehasonlításképpen az angol és a szlovák kötet társalgási témakörei: Angol nyelvmester: 1) Az angol beszédről. 2) Bankárnál. 3) Boltban. 4) Búcsút venni. 5) Czipészszel. 6) Dohányzásról. 7) Ebéd. 8) Étterem. 9) Fölkelni. 10) Gőzhajón. 11) Játékok. 12) Az időről. 13) Irásról. 14) Kávéház. 15) Kérni. 16) Kivándorlás. 17) Korról. 18) Könyvkereskedőnél. 19) Köszönni. 20) Köszöntések. 21) Látogatás. 22) Lefekvésról. 23) Öltözködni. 24) Óra. 25) Orvossal. 26) Posta. 27) Reggeli. 28) Sétálás. 29) Sörről. 30) Szállodában. 31) Társaskocsi. Bérkocsi. 32) Tudakozódni valaki után. 33) Ujdonságok. 34) Utlevél hivatalban. 35) Út után kérdezni. 36) Vacsora. 37) Vámhivatal. 38) Vasuton. 39) Vendéglőben. 40) Mindenféle. Tót nyelvmester: 1) A tót nyelvról és a tótokról. 2) Az időről. 3) Az idő (óra). 4) A kor. 5) Az utczán. 6) Reggel. 7) A reggeli. 8) Ebéd. 9) Vacsora. 10) Este. 11) Az orvos. 12) Az utazás. 13) Budapesten. 14) A czipész. 15) A szabó. 16) A boltban. 17) Látogatáson. 18) Irás. 19) Hónapok és napok. 20) A legszokottabb nyelvsajátságok. 21) A kőmúves munka. 22) A magyar gazda és a tót napszámos. 23) Utazás a külföldre. 24) Udvarias kifejezések; egyszerú mondatok. 25) Közmondások. 
Japán nyelvmester (p. 47): Shuppan no toki wo watashi ni chanto shirasete kuremasu ka?

GJU (p. 105.): shuppan no toki wo watakushi ni chanto shirasete kuremas'ka.

Azonban a társalgási kifejezések nagy része nem magyarázható Seidel munkáiból, így feltehetóen Akantisz önállóan állította ôket össze, vagy pedig egy jelenleg még ismeretlen forrást vehetett alapul.

\section{A szójegyzék}

A magyar-japán szótár 1325 szócikkből áll, és több évtizeden át az egyetlen ilyen szójegyzék lehetett, ami nyomtatásban is megjelent. ${ }^{19} \mathrm{~A}$ japán szavak itt is latin betús átírásúak, de egyes esetekben zárójelben megadja a „kiejtés pontos feltüntetését”:

p. 48.: augusztus hó, hachigwatsu ${ }^{20}$ (hacsi nguacz);

p. 49.: elutazás, shuttatsu, hossuku [sic!] (suttacz);

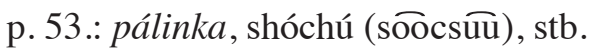

19 Bár az első világháborúban orosz fogságba kerültek között volt olyan, aki megtanult valamilyen szinten japánul, és japán szójegyzék összeállításába kezdett (Udvardi 1996: 44, Umemura 2006: 114-118), az első nyomtatásban is megjelent szótár Imaoka Jūichirō 今岡 十一郎 (Magyar-japán és japán-magyar zsebszótár, Tokió, 1943) és Metzger Nándor (Nagy magyar-japáni szótár, I. kötet, Tokió, 1945) nevéhez füződik.

20 A kwV és a gwV típusú szótagok (gōyōon 合拗音) elsősorban a sino-japán szavakra jellemzőek, de később az eredeti japán szavakban is megjelentek. Azonban a sino-japán kwi/kwe, gwi/gwe helyét már a Muromachi-korszak előtt átvette a ki/ke, gi/ge (chokuon 直音), de a kwo még megtalálható a kirishitan anyagokban. A kwa $\rightarrow$ ka, gwa $\rightarrow$ ga változás az Edo-kor végén, különösen Edóban gyorsult fel, de a múvelt rétegek beszédében még előfordulhatott az eredeti gōyōon kiejtés. Ez a tendencia a Meiji-korban is megfigyelhetô. A Japán nyelvmesterben 27 olyan sino-japán összetétel van, amelyben eredetileg gōyōon volt, de ezek közül 5 már chokuon kiejtésben szerepel. Ezeket a szavakat összevetve Seidel munkáival azt találjuk, hogy míg a PGJS a Japán nyelvmesterhez hasonlóan ezt a múveltebbnek számító kiejtést részesítette elónyben, addig a későbbi tankönyvekben vagy mindkét változat, vagy csak a chokuon kiejtés került rögzítésre. 
A szófaji besorolást nem adja meg. Melléknevek esetében az -i végú beszélt nyelvi alak és a $-k i$ végú írott nyelvi alak egyaránt megtalálható. Néhány példa: p. 49.: drága, takai; p. 49: édes, amaki; p. 53. olcsó, yasuki, yasui stb.

Az igealakok jelölése is ingadozó: határozói alak (ren'yōkei 連用形), zárójelben a záróalak (shūshikei 終止形): p. 52.: kifizetni, harai(-u) - csak határozói alak; p. 49.: épiteni, tate - csak záróalak; p. 51.: képet festeni, e kaku - írott nyelvi alak; p. 55.: ugatni, hoyu stb.

A fentiekből arra lehet következtetni, hogy Akantisz többféle forrást is felhasználhatott a szójegyzék összeállításakor. Ebben találhatók olyan hibás értelmezések is, amelyek arra utalhatnak, hogy Akantisz német nyelvú szótárakat, szójegyzékeket vehetett alapul. Néhány példa a félrefordításokból:

p. 48.: adó, zei, kaji (kazsi): A zei 税 jelentése 'adó', a kaji 舵 vagy 梶 jelentése 'hajókormány'. Német nyelven az elóbbi die Steuer, az utóbbi das Steuer.

p. 49.: erős, matsuri: A matsuri 祭り jelentése '(vallási) ünnep, fesztivál', itt a fónévi das Fest és a melléknévi fest összekeverése okozhatta a hibát.

p. 56.: vár, jó mae: A jōmae 錠前 jelentése 'zár(szerkezet)', Akantisz itt feltehetôen a das $S c h l o \beta$ kétféle jelentését keverhette össze.

A szójegyzékben találhatók olyan további hibás értelmezések is, amelyek Seidel munkáira vezethetők vissza:

Japán nyelvmester p. 49.: czilinder (kalap), eboshi

PGJS p. 166.: der Cylinder yebossi (lábjegyzetben: ,aus steifem, schwarz lackirtem Lederpapier, unter dem Kinn durch ein Band befestigt")

A japán szó magyarázata Hepburnnél (A Japanese-English and English-Japanese Dictionary. Tōkyō 1886): EBOSHI アボシ 烏帽子 $\mathrm{n}$. A kind of cap worn on the crown of the head by nobles, also by Manzai and Kannushi. 
Japán nyelvmester p. $54 .:$ proletár, eta

PGJS p. 182.: das Proletariat yeta (Schinder, Gerber und Lederarbeiter; sie besorgen auch das Geschäft des Todtengräbers.)

Hepburn: ETA 卫夕穢多 n. A class of persons occupying the lowest social position. They follow the occupation of leather-dressers, or buriers of dead animals; they are compelled to live separate from others and not allowed to enter the house, to sit or cook at the same fire with persons out of their own class. (This distinction of caste has recently been abolished by the Imperial government.)

Valószínúleg sortévesztésen alapuló elírás:

Japán nyelvmester p. 54.: pók, kumo; pókháló, fukurogumo.

SWJU p. 69.: kumo, Spinne; kumo no su, Spinngewebe; fukurogumo, Tarantel.

Összefoglalva az eddigieket, Akantisz a magyar-japán szójegyzék összeállításakor német forrásokat, köztük Seidel nyelvkönyveit és szótárát használhatta fel. 


\section{A japán írásrendszer és szövegmutatvány}

A könyv utolsó fejezete a japán szótagírás magyarázatából és táblázataiból, a számokat jelölő kínai írásjegyekből, valamint egy szövegmutatványból áll. A kutatás során bizonyossá vált, hogy ez a rész is Seidelre vezethető vissza, és a GJS alábbi oldalain alapul:

\begin{tabular}{l|l}
\hline Japán nyelvmester & $\begin{array}{l}\text { Grammatik der japanischen } \\
\text { Schriftsprache }\end{array}$ \\
\hline pp. 56-60. A japáni írásról & pp. 106-110; 113-114; 138. \\
\hline pp. 61-64. Japáni írásminták & pp. 91-94; 111-113; 115-117; 141-143. \\
\hline
\end{tabular}

Bár az 1900. évi elemi iskolai oktatással kapcsolatos rendelettel (shōgakkōrei 小学校令) egységesíteni kívánták a hiragana és a katakana szótagírást, a gyakorlatban ezt nem tudták maradéktalanul teljesíteni. ${ }^{21}$ A Japán nyelvmester táblázataiban is keverednek a standardizált és alternatív formák: a hiragana [o] [so], a katakana [ne] [wi] esetében találunk alakváltozatot. A szótagok hosszítása a korábbi gyakorlattal szakítva, elsősorban a nyújtójel (一) segítségével történik, azonban a Japán nyelvmester megjelenése után három évvel, 1908-ban Japánban visszaálltak a történelmi kana-használatra (rekishiteki kanazukai 歴史的仮名遣い). ${ }^{22}$

A szövegmutatvány a Zhànguó cè 戰國策 (Chǔcè 楚策) címú kínai múből ${ }^{23}$ származó „A tigris és róka története”, és a következő négyféle írásmóddal kerül bemutatásra: latinbetús átírás, katakana, hiragana, kanji-kana vegyesírás (lásd a képmellékletben). A japán szavak mellett a magyar megfelelőjük, a szövegmutatvány végén pedig a teljes magyar fordítás olvasható. Ez a szöveg is a GJS-ből származik, amelyben ezen kívül még öt olvasmány található. Felmerül a kérdés, hogy Akantisz vajon miért pont ezt választotta?

21 Takashiro 2011: 103-112.

22 Kakigi 2007: 127-130.

23 Az eredeti kínai szöveg: 虎求百獸而食之, 得狐。狐曰, 子無敢食我也! 天帝使我長百 獸。今子食我, 是逆天帝命也。子以我爲不信, 吾爲子先行。子隨我後觀。百獸之 見我, 而敢不走乎。虎以爲然, 故逐與之行。獸見之皆走。虎不知獸畏已而走也, 以爲畏狐也。 
A GJS-ben Seidel hat szövegmutatványt ${ }^{24}$ tesz közzé a következő írásmódokban:

1. latin betû́s átírás: Kaiko, Tora to kitsune to no hanashi, Tsubame, Tsubame no su o ubaishi suzume no hanashi, Inu no chie, Higashi no kata yori kitarishi hakasetachi;

2. katakana szótagírás: カイコ [kaiko], トラトキツ子 卜ノ ハナシ [tora to kitsune to no hanashi];

3. hiragana szótagírás: かいこ [kaiko], とらときつねと [sic!] はなし [tora to kitsune to hanashi];

4. kanji-kana vegyesírás: 楓 [kaiko], 虎と狐との話 [tora to kitsune to no hanashi], 燕 [tsubame], 燕の巢をうばいし 雀の話 [tsubame no su o ubaishi suzume no hanashi], 犬 の智慧 [inu no chie].

Látható, hogy csak két olvasmány van mind a négyféle írásmóddal lejegyezve. A Kaiko (Selyemhernyó) tulajdonképpen egy magyarázó szöveg, ezzel szemben a Tora to kitsune to no hanashi (A tigris és róka története) hasonlít Aisôpos meséire, amit a nyelvtanulók is érdekesnek találhattak, emiatt dönthetett Akantisz ezen történet mellett.

\section{Befejezés}

Az eddig ismertetett források alapján feltételezhetjük, hogy 1) a Japán nyelvmester összeállítója Akantisz Viktor; 2) Akantisz elsősorban a német August Seidel munkáit használhatta fel a könyv megírása során. Bár vannak hibái,

24 A GJS előszavában olvasható, hogy „Die Lesestücke sind japanischen Werken entnommen”, de Seidel nem nevezi meg konkrétan a forrásait. Azonban egy olvasmány az Újszövetség japán fordításából származik, a maradék öt pedig megtalálható az 1887-ben megjelent Jinjō shōgaku tokuhon 尋常小學讀本 címú olvasókönyv harmadik és negyedik kötetében. Mivel a kana-használatban és a szókincsben kimutatható minimális eltérésen kívül a szövegek megegyeznek, valószínúsíthetô, hogy Seidel iskolai tankönyvből - esetleg a Jinjō shōgaku tokuhon egy későbbi kiadásából - vehette a szövegmutatványokat. 
hiányosságai, az első magyar nyelven íródott japán nyelvtanként mégis úttörőnek számít a magyarországi japán nyelvoktatás-nyelvkutatás terén.

Tisztázatlan probléma a könyv fogadtatása, értékelése, illetve az esetleges további kiadások megléte. Érdemes megjegyezni, hogy a Japán nyelvmester egy példánya megtalálható a Japán Országgyúlési Könyvtárban is. ${ }^{25}$ Ebben az első oldal tetején a könyvtár bélyegzője, a lap alján pedig a következó pecsét látható: 明治43年10月3日 寄贈 [Meiji 43 nen 10 gatsu 3 ka kizō], amiből megállapítható, hogy a könyvet 1910. október harmadikán adományozták a könyvtárnak. A könyvtár jóindulatának köszönhetően betekinthettem a korabeli feljegyzésekbe is, ahol az adományozó neve is feltüntetésre került. A név öt kanjiból áll, amelyből az első kettő az 井上 [Inoue] családnevet takarja. A maradék három írásjegy nehezen azonosítható, de a Dōshisha Női Egyetem 同志社女子大学 professzora, Yoshikai Naoto 吉 海直人 segítségével sikerült az elsôt kiolvasni. A kérdéses írásjegy a 正, amelynek névként lehet [masa] vagy [shō] olvasata is. Az adományozó teljes neve és az adományozás körülményei szintén megoldásra várnak.

\section{Elsődleges források}

Alcock, Rutherford 1861. Elements of Japanese Grammar for the use of Beginners. London: Trübner and Co.

Aston, W. G. 1888. A Grammar of the Japanese Spoken Language. (4. kiadás.) Tokyo: Hakubunsha.

Baba, Tatui 1888. An Elementary Grammar of the Japanese Language. (2. bőv. kiadás) London: Trübner and Co.

Brown, S.R. 1863. Colloquial Japanese. Shanghai: Presbyterian Mission Press.

Chamberlain, Basil Hall 1886. A Simplified Grammar of the Japanese Language (Modern Written Style). Yokohama: Kelly and Walsh.

$25 \mathrm{Ba}-352$. 
Chamberlain, Basil Hall 1898. A Handbook of Colloquial Japanese. London: Sampson Low.

Courant, Maurice 1899. Grammaire de la Langue Japonaise Parlée. Paris: Ernest Leroux.

Curtius, Donker 1857. Proeve eener japansche Spraakkunst. Leiden: A.W. Sythoff.

Evrard, Félix 1874. Cours de Langue Japonaise en soixante leçons. Yokohama: L’Écho du Japon.

Hoffmann, J.J. 1868. A Japanese grammar. Leiden: A.W. Sythoff.

Noack, Philipp 1886. Lehrbuch der japanischen Sprache. Leipzig: F.A. Brockhaus.

Rosny, de Leon 1873. Éléments de la Grammaire Japonaise (langue vulgaire). Paris: J. Maisonneuve.

Rozsnyai gyors nyelvmesterei. Angol. Budapest: Rozsnyai Károly.

Rozsnyai gyors nyelvmesterei. Japán. Budapest: Rozsnyai Károly.

Rozsnyai gyors nyelvmesterei. Tót. Budapest: Rozsnyai Károly.

Seidel, August 1890. Praktische Grammatik der japanischen Sprache. Wien: Hartleben.

Seidel, August 1901. Grammatik der japanischen Umgangsprache. Wien: Hartleben.

Seidel, August 1904. Grammatik der japanischen Schriftsprache. Wien: Hartleben.

Seidel, August 1904. Systematisches Wörterbuch der japanischen Umgangssprache. Oldenburg: Schwartz. 
Weintz, H. J. 1905. Appendix to Hossfeld's Japanese Grammar. London: Hirschfeld Brothers.

\section{Felhasznált másodlagos szakirodalom}

Brockhaus' Kleines Konversations-Lexikon, Band 2. [Ötödik kiadás] Leipzig 1911.

Brockhaus' Konversationslexikon [Tizennegyedik kiadás] Berlin und Wien, 1894-1896.

Gulyás Pál 1939. Magyar írók élete és munkái I. kötet. Budapest: Magyar Könyvtárosok és Levéltárosok Egyesülete.

Harangi László 1982. „Nihon kankei hangarīgo bunken (1851-1980 nen) 日本関係ハンガリ一語文献（1851-1980年）[Japánra vonatkozó magyar múvek bibliográfiája 1851 és 1980 között].” In: Nihon to tōō shokoku no bunka kōryū ni kansuru kisoteki kenkyū 日本と東欧諸 国の文化交流に関する基礎的研究 [Japán és Kelet-Európa országainak kulturális kapcsolatrendszerével kapcsolatos alapkutatások], Tokyo: Nihon tōō kankei kenkyū kai, 376-417.

Kakigi Shigetaka 柿木重宜 2007. „Kokugokyōiku ni okeru bōhiki kanazukai no hensen ni tsuite 国語教育における「棒引仮名遣い」の変 遷について [A nyújtójel használatának változásai az anyanyelvi oktatás terén]." Zenkoku daigaku kokugokyōiku gakkai happyō yōshishū 全国大学国語教育学会発表要旨集113: 127-130.

Kondō Masanori 近藤正憲 2005. „20 seiki shotō hangarī de shuppan sareta nihongo kyōkasho to sono jidaihaikei 20世紀初頭ハンガリーで 出版された日本語教科書とその時代背景 [A 20. század elejének Magyarországán megjelent japán nyelvkönyv és annak háttere].” Sekai no nihongokyōiku 世界の日本語教育15: 175-192. 
Pukánszkyné Kádár Jolán 1972. „A Todoreszku-Horváth-gyújtemény.” Magyar Könyvszemle 88: 52-60.

Révay József 1929. A Magyar Könyvkiadók és Könyvkereskedók Országos Egyesületének ötven éve. Budapest: A Magyar Könyvkiadók és Könyvkereskedők Országos Egyesülete.

Takashiro Kōichi 高城弘一 2011. „Meiji sanjūsannen shōgakkōrei ni yoru kana no tōitsu to konran 明治三十三年「小学校令」による仮名の 統一と混乱 [A kana szótagírás standardizálása és a jelváltozatok keveredése az 1900. évi elemi iskolai oktatással kapcsolatos rendelet hatására].” Jissen joshi tankidaigaku kiyō 実践女子短期大学紀要 32: 103-112.

Tóth Gergely 2010. Birodalmak asztalánál. A monarchiabeli Magyarország és Japán kapcsolattörténete 1869-töl 1913-ig, korabeli és új források alapján. Budapest: Ad Librum.

Udvardi Lázár 1996. Emlékeim a hadifogságból 1914-1920. Bajai dolgozatok 10. Baja: Türr István Múzeum.

Umemura Yuko 2006. A Japán-tengertól a Duna-partig. Budapest: Gondolat. 
Képmelléklet

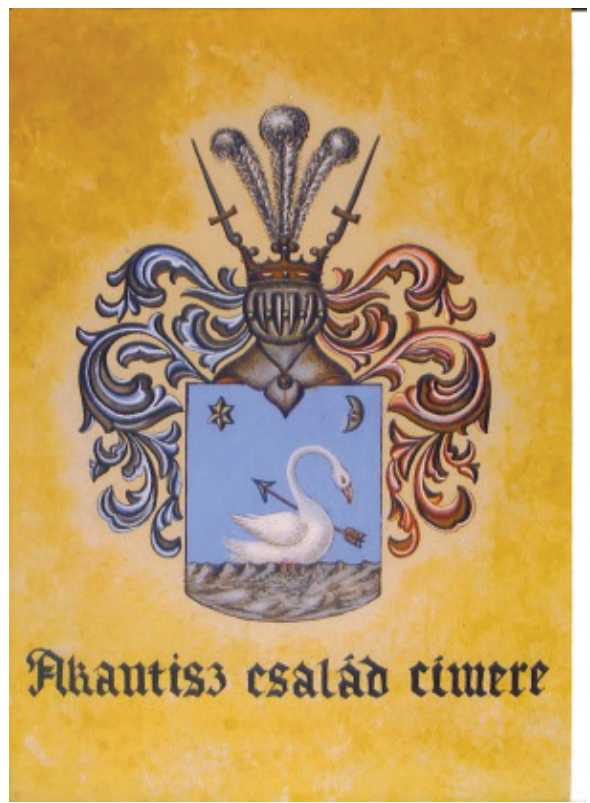

Az Akantisz család címere. Vincze-Pikó Adrienn tulajdona. 


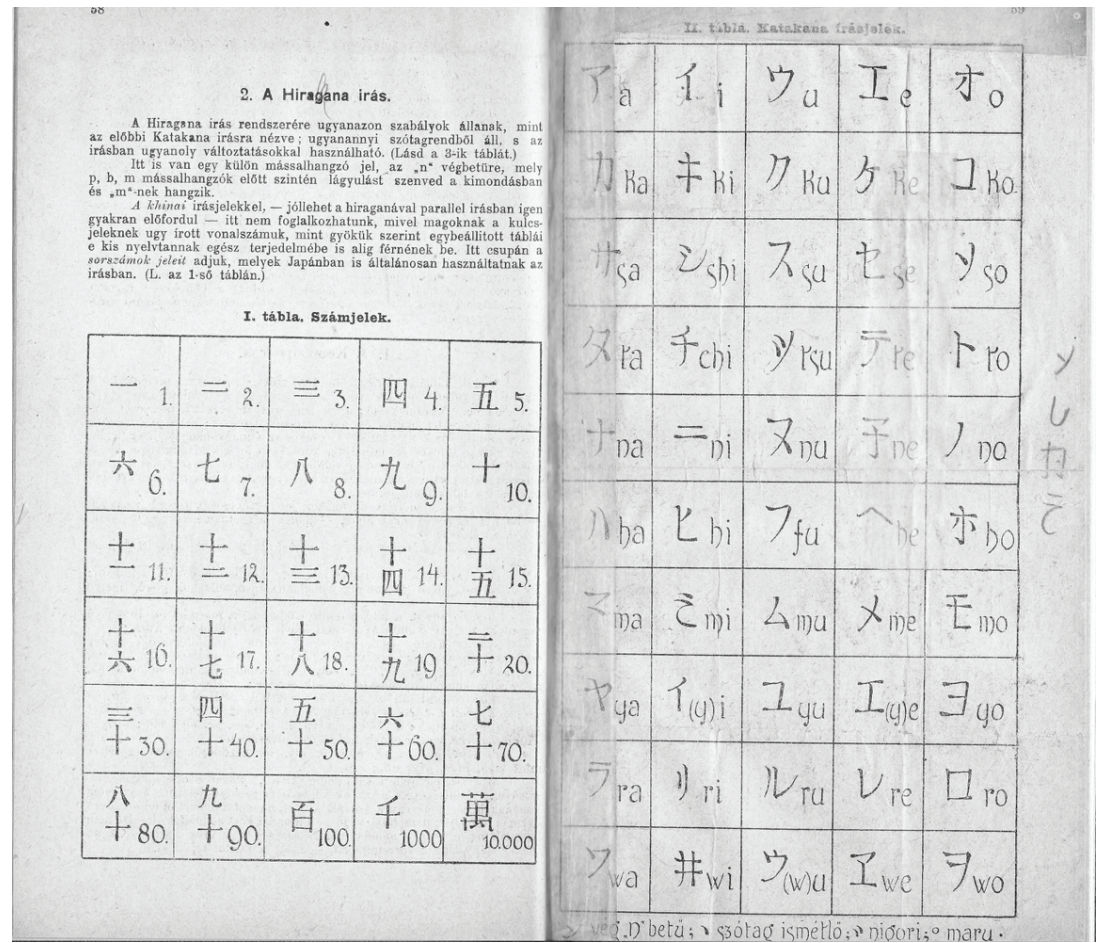

Az I-II. írástábla a Japán nyelvmesterben. Albeker András tulajdona. 


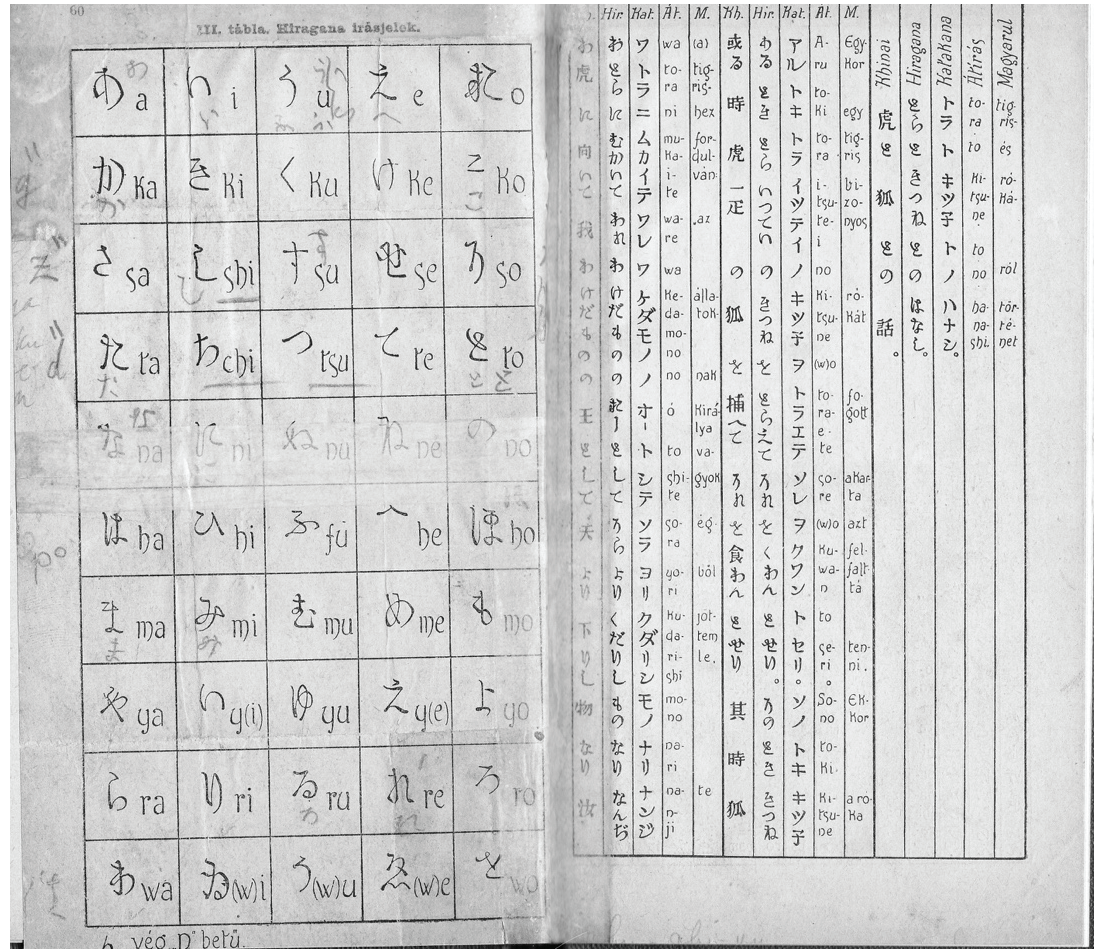

A III-IV. írástábla. Albeker András tulajdona. 


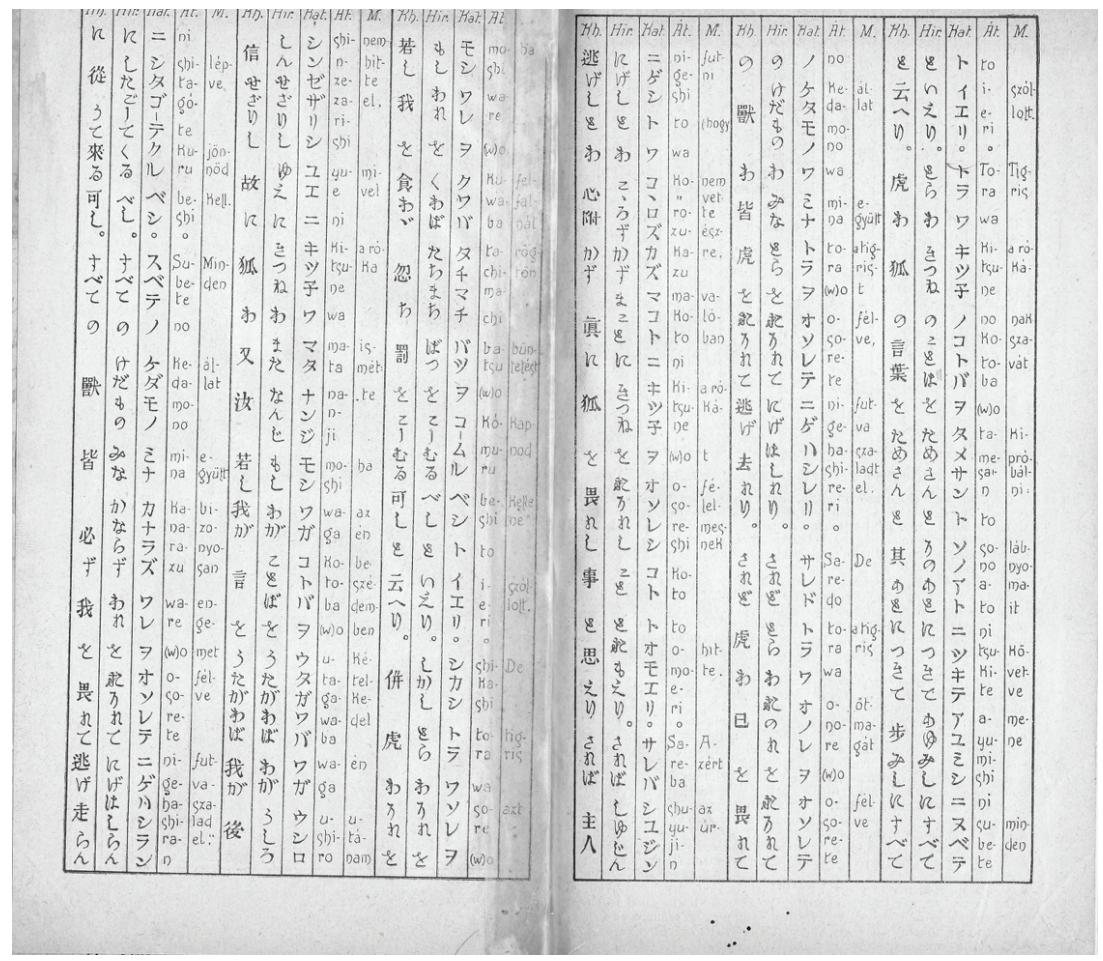

Az V-VI. írástábla. Albeker András tulajdona. 


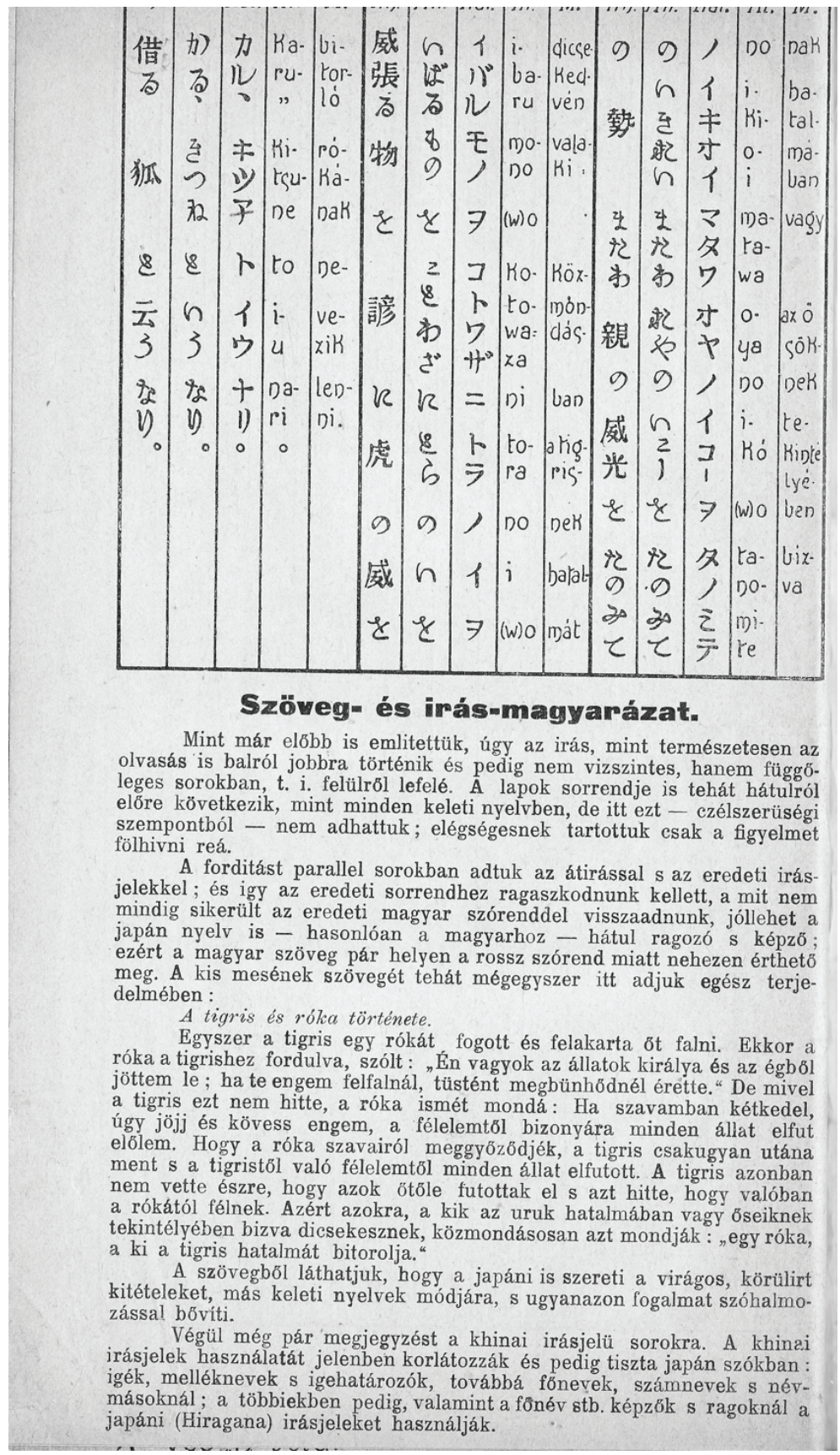

A VII. írástábla, valamint a magyarázatok. Albeker András tulajdona. 